\title{
Influence of Human Capital on Organizational Performance as Mediated by Management Control System and Operational Risk Management
}

\author{
Williams Kwasi Peprah, Ph.D. CSSB, F.cfia \\ Valley View University, Accra, Ghana, School of Business \\ Agnes Riziki Lufungula, Ph.D, CPA \\ Institut Superiuer de Commerce, ISC/Butembo DRC, Democratic Republic of Congo
}

\begin{abstract}
Today, business in our world is experiencing systemic failures that affect the performance of the company. Mostly, through the use of financial measurements, corporate success is viewed at their level of effectiveness. This study explored the mediating effect of the management control system and operational risk management on the impact of human capital on organizational performance. This was a quantitative research with a correlational research design. The study employed self-constructed research instruments with Cronbach Alpha of human capital 0.893, Organizational performance 0.855 , and operational risk management 0.833 and management control system 0.894 . The respondents were made up of $439(10 \%)$ of the Institute of Chartered Accountant Ghana members who were conveniently sampled and answered an online distributed questionnaire. The results of the study revealed that management control system and operational risk management partially mediate the relationship between human capital and organizational performance. The research recommends that the intervention role of the management control system and operational risk management has shown to impact positively on organizational performance and human capital. Therefore, the implementation of a management control system and operational risk management must be paramount to the achievement of organizational performance from the viewpoint of chartered accountants in Ghana.
\end{abstract}

Keywords: Human Capital, Operational Risk Management, Management Control System, Organizational Performance.

DOI: $10.7176 /$ RJFA/11-10-08

Publication date:May $31^{\text {st }} 2020$

\section{Introduction}

Today, business in our world is experiencing systemic failures that affect the performance of the company. Mostly, through the use of financial measurements, corporate success is viewed at their level of effectiveness. Such organizational performance deficiencies are the product of fraud, theft, negligence, environmental hazards, and human error risk factors. Such activities include business risk, human capital, and oversight of management. Risk caused by uncertainty can affect business performance either positively or negatively (Project Management Institute (PMI), 2008). According to the research of Weeserik and Spruit (2018), however, risk management affects all sectors and it is true that most large firms have failed in the past.

In other to name a few organizational performance failures as a result of operational risk failures and its consequences, this dissertation recounts in the 1990s Daiwa Bank in the USA with \$1billion loss in bankruptcy, Ihalas Finance House Turkey (Barth, Carprio \& Levine, 2008). Barings Bank \$1.4billion loss and Allied Irish Bank \$691.2m loss in 2002, National Australia Bank’s \$360m loss in 2004 (Etu-Menson, 2011). A recent case in Africa is in Ghana where collapse of seven commercial banks namely Sovereign Bank, The Beige bank, The construction Bank (Gh) Ltd, The Royal Bank, UniBank, Capital Bank and UT Bank has caused the country to save the financial sector with $\$ 1$.2billion (Peprah, 2018). The great operation risk management failures that can be remembered are Enron and Lehman Brothers Bank. The collapse of these institution affected investors, shareholders, professionals, and academicians in their understanding and practices of operational risk management (Bamahros \& Bhasin, 2016).

Operational risk management is continuous risk management in human actions, process and systems, and external events (Weeserik \& Spruit, 2018). It involves human capital in decision making and a deviation from a specified routine (Gygi \& Williams, 2012). Operational risk management is a methodology to improve cost, technical performance, and schedule (Oehmen, Olechowsk, Kenley \& Ben-Daya, 2014). In all these understanding, operational risk impacts on organizational performance. The elements of human capital or intellectual capital are considered as an intervening variable (Peprah, 2019)). It is a procedural way of alleviating the negative consequences of any phenomenon. The risk is benefited with some opportunities so firms need human intellectual capital who can manage the business process efficiently and effectively to impact organizational performance positively. 
According to Kloosterman (2014) operational risk management logically starts from identification, analyzing, evaluation or ranking, treatment and monitoring, and revision. All these activities require having the right human capital amidst proper management control to achieve favorable organizational performance. This procedure is needed to address the internal failure of processes, systems as a result of weakness from external events, human capital and management control (Ragian et al., 2014).

Again, organizational performance has long been studied with models as proposed by Kaplan and Norton in 1992 and 1996 on balanced scorecard, Lynch and Cross in 199 with performance pyramid system and Neely, Adams, and Kennerley in 2002 on performance prism. However, Felizardo, Felix, and Thomaz (2017) have posted the questioned on what to measure and how to measure? This makes this variable must difficult to explain. These measurements are on the processes, people and outcome.

Furthermore, Mohammed and Knapkova (2016) in the Czech Republic studied the impact of total risk management o firms' performance. Their results showed that there is a positive relationship between total risk management and company performance as intervening by investment in intellectual capital. The study did not factor the role of management control systems and moderating variables of size, location and years of operation. Further, their studies focused on companies and not health institutions.

This study seeks to fill the knowledge in gap with the impact of the mediating effects of management control systems and operational risk management on the relationship between human capital and organizational performance from the perspective chartered accountants in Ghana. The research seeks to answer the following research question:

1. Do management control systems and operational risk management mediate the relationship between human capital and organizational performance?

The null hypothesis:

1. Management control system and operational risk management do not mediate the relationship between human capital and organizational performance.

In relation to its operational efficiency, the intent of company life has changed over time. According to Mortin and Audebrand (2014), not only must the measurement of corporate success consist of financial factors of investment return, income per share, revenues. The human capital, process, and environment must be considered. The organizational success of modern times is based on development, competitiveness, financial performance, social cooperation, and human dignity. The aim is to satisfy shareholders, clients, and employees ' needs and desires. This is because, after the shareholder's satisfaction, human capital can affect the consumer (Mortin \& Audebrand, 2014).

Management control systems are systems and procedures using the information to maintain or change organizational activity patterns (Arjaliès \& Mundy, 2013). Management control systems are methods and strategies to reduce the company's waste and firms' uncertainties. Such methods are used to measure human capital, process and financial performance on objects and strategies set (Hauge, \& Kanden, 2017). Every human activity's control elements must be one that is a detector, evaluator, and effector and that communicates. Management control is concerned with resource allocation, coordination, motivation, and analysis of performance (Junqueira, Dutra, Zanquetto \& Gonzaga, 2016). Management control systems are therefore assessment instruments to assess, measure and classify the success of the company. It should be remembered that due to the complex events in industry, these control systems vary.

Risk is on every manager's minds. This is because increasing company often raises the level of risk as the pace of risk increases (Fraser, Simkine \& Narvaez, 2014). Operational risk management is a sub-set of organizational risk management as defined by the Treadway Commission's Committee of Sponsoring Organizations (COSO, 2004). Operational risk is concerned with any company's internal control deficiencies as they relate to identifying, preventing and fixing them (Mitra, Karathanasopoulos, Sermpinis, Dunis \& Hood, 2015). As a result of human resource considerations, procedures, and incidents, these internal control deficiencies occur.

A significant statement regarding human capital by Peprah and Ganu (2018) is that in the midst of technology, product creativity and low cost to conquer competitors; human capital is the cornerstone of every productive organization. Adam Smith based his work more on human capital during the capitalist era in 1776. Adam Smith's components of human capital included the individual's schooling, apprenticeship, talent, and skills. The concept of human capital based on macroeconomic theory considers individuals as the most valuable asset for the company's growth and establishment (Bhattacharya, 2014). It is this concern that leads organizations to "invest in people in the form of training and development, improving work-life quality, promoting work-life balance, improving overall health, among other things, improving people's asset value" (Bhattacharya et al., 2014, p. 1).

Fechete and Nedelcu (2014) also examined how risk assessment under operational risk management affects organizational performance among manufacturing firms in Romania. They also scrutinized how the management behaved when it comes to risk. The study established that it is essential to identify risk factors which will help the firm find treatment for it. It noted that profitability analysis help to recognize the risk. They recommended that good management must be rational and not put an effort to avoid risk but instead through discipline and 
methodology control risk and its impact.

Oehman, Olechowski, Kenley, and Ben-Daya (2014) admitted that operational risk management is receiving much attention in helping to improve cost, technical performance and schedule. They used survey respondents of 291 to investigate the risk management practices on program stability, quality decision making, open problem solving, product success and project success.

Channa, Abbasi, and Maheshwari (2015) comparative study between Islamic and Conventional Banks resulted in a mixture based on the relationship between operational risk management and organizational performance. The Islamic banks showed a negative non-significant relationship while the conventional banks resulted in a positive relationship. The statistical study treatment was t' test and correlation. The data used were both primary and secondary financial data.

\section{Method}

The research design is a correlational study. It is a quantitative study that analyzes the data using parametric inferential statistics. This study's respondents were members of the Institute of Chartered Accountants, Ghana (ICA). According to data from ICA, Ghana, there were 4,390 chartered members in good standing as of May 2019 and $439(10 \%)$ members were conveniently sampled for the study at a confidence interval of $95 \%$ based on Creative Research Systems survey software. The respondents answered self-constructed questionnaires, which had an internal consistency of human capital 0.893 , Organizational performance 0.855 , operational risk management 0.833 and management control system 0.894 Cronbach Alpha. The Cronbach alpha interpretation will be based on George and Mallery (2003) rules of thumb stated that " $>>.9-$ Excellent, $>>.8-$ Good, $>>.7-$ Acceptable, $>.6$ - Questionable, $>$ > .5 - Poor, and $<.5$ - Unacceptable” (p. 231) which indicated that the instruments were good to use for the study.

The scoring system for the mediation as analysis with the application of IBM SPSS AMOS v23 is based on the indications in table 1:

\section{Table 1}

Scoring table for Model Fit

\begin{tabular}{lll}
\hline \multicolumn{1}{c}{ Fit Measure } & Good Fit & Acceptable Fit \\
\hline Chi square & $0 \leq \chi^{2} \leq 2 \mathrm{df}$ & $2 \mathrm{df}<\chi^{2} \leq 3 \mathrm{df}$ \\
p value & $.05<\mathrm{p} \leq 1.00$ & $.01 \leq \mathrm{p} \leq .05$ \\
RMSEA & $0 \leq \mathrm{RMSEA} \leq .05$ & $.05<$ RMSEA $\leq .08$ \\
CFI & $0.97 \leq \mathrm{CFI} \leq 1.00$ & $0.95 \leq \mathrm{CFI}<.97$ \\
GFI & $0.95 \leq \mathrm{GFI} \leq 1.00$ & $0.90 \leq \mathrm{GFI}<.95$ \\
\hline
\end{tabular}

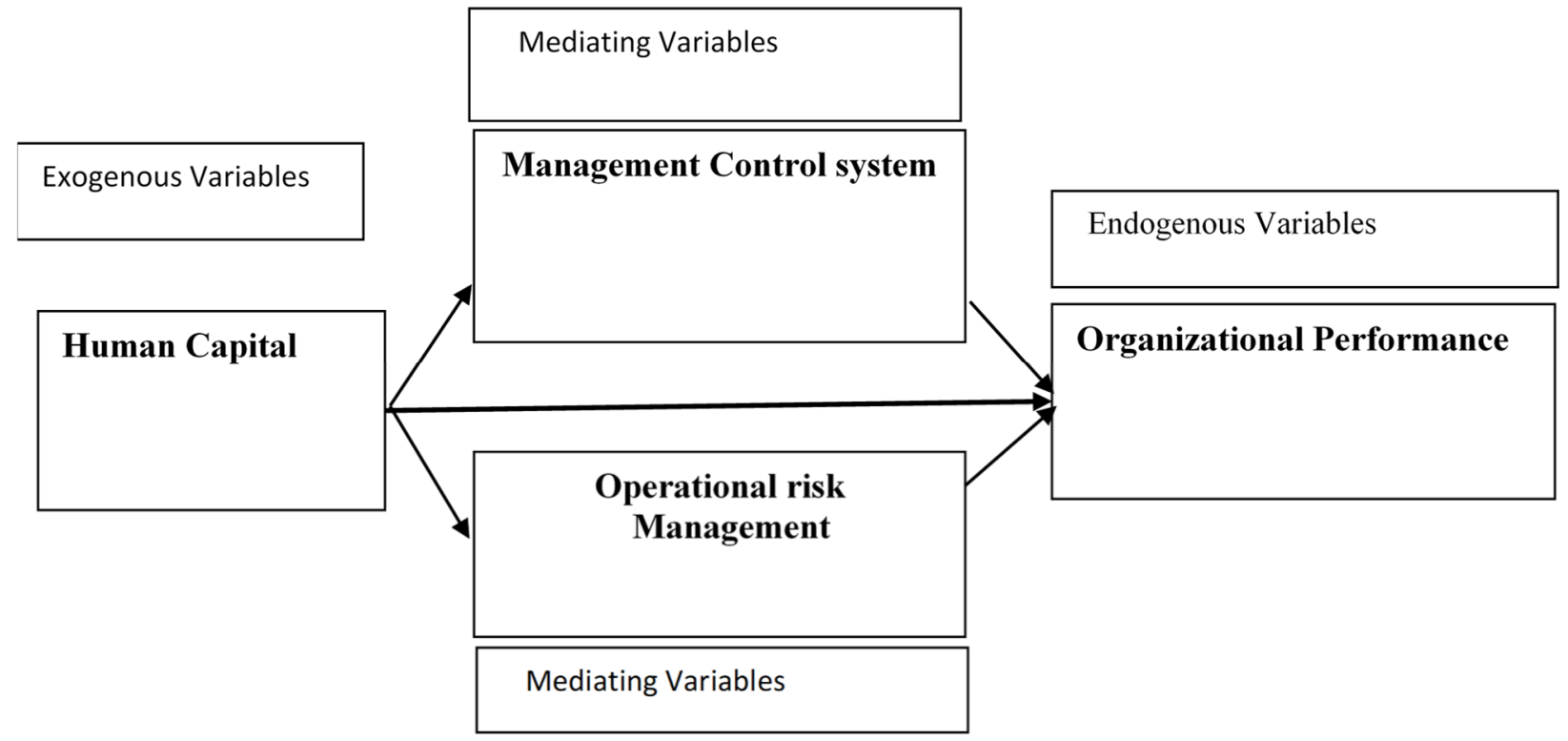

Figure 1. Conceptual Framework

\section{Results}

Baron and Kenny (1986) noted that before mediation study is done the relationship between the independent variables and dependent variable must be established. The role of the mediator is to given an account of the relationship or explain why and an effect occurs. The study looked at the mediating effect of management control 
system and operational risk management on the relationship between human capital and organizational performance.

The path regression model of the relationship showed that both mediators of management control system and operational risk management have a significant mediating effect on the relationship human capital and organizational performance as shown in Table. The mediating effect of management control system on the relationship between human capital and organizational performance was partial and with a magnitude effect of high (Estimate $=.507, \mathrm{p}=.003$ ). Furthermore, the mediating effect of operational risk management on the relationship of human capital and organizational performance was also partial and with a magnitude effect of high (Estimate $=.785, \mathrm{p}=.004)$

Table 2

Summary Table for Mediation Results

\begin{tabular}{|c|c|c|c|c|c|c|c|c|c|}
\hline IV & Mediator & DV & Type & $\begin{array}{l}\text { Estimat } \\
\text { e }\end{array}$ & $\begin{array}{l}\text { Lowe } \\
\mathrm{r}\end{array}$ & $\begin{array}{l}\text { Uppe } \\
\text { r }\end{array}$ & $\begin{array}{l}\mathrm{p}- \\
\text { valu } \\
\mathrm{e}\end{array}$ & $\begin{array}{l}\mathrm{I} \\
\mathrm{V}\end{array}$ & $\begin{array}{l}\text { Magnitud } \\
\text { e }\end{array}$ \\
\hline Human & $\begin{array}{l}\text { Managemen } \\
\text { t Control }\end{array}$ & Organizationa & Partia & & & & 0.00 & & \\
\hline Capital & $\begin{array}{l}\text { System } \\
\text { Operational } \\
\text { Risk }\end{array}$ & 1 Performance & 1 & 0.507 & 0.485 & 0.680 & 3 & $\mathrm{~S}$ & High \\
\hline Human & Managemen & Organizationa & Partia & & & & 0.00 & & \\
\hline Capital & $\mathrm{t}$ & 1 Performance & 1 & 0.785 & 0.685 & 0.795 & 4 & $\mathrm{~S}$ & High \\
\hline
\end{tabular}

$\mathrm{IV}=$ Independent Variable, DV=Dependent Variable, $\mathrm{S}=$ Significant, Type= Mediation Type

Table 3

Regression Model for Management Control and Operational Risk Management as Mediator

\begin{tabular}{|c|c|c|c|c|c|c|c|c|}
\hline & & & Estimate & S.E. & C.R. & $\mathrm{P}$ & Label & VI \\
\hline $\begin{array}{l}\text { Management Control } \\
\text { System }\end{array}$ & $<---$ & Human Capital & 1.239 & 0.032 & 39.029 & $* * *$ & par_1 & $\mathrm{S}$ \\
\hline $\begin{array}{l}\text { Operational Risk } \\
\text { Management }\end{array}$ & $<---$ & Human Capital & 1.362 & 0.03 & 45.164 & $* * *$ & par_2 & $\mathrm{S}$ \\
\hline $\begin{array}{l}\text { Organizational } \\
\text { Performance }\end{array}$ & $<---$ & $\begin{array}{l}\text { Management Control } \\
\text { System }\end{array}$ & 0.096 & 0.043 & 2.254 & 0.024 & par_3 & $\mathrm{S}$ \\
\hline $\begin{array}{l}\text { Organizational } \\
\text { Performance }\end{array}$ & $<---$ & $\begin{array}{l}\text { Operational Risk } \\
\text { Management }\end{array}$ & 0.333 & 0.045 & 7.415 & $* * *$ & par_4 & $\mathrm{S}$ \\
\hline $\begin{array}{l}\text { Organizational } \\
\text { Performance }\end{array}$ & $<---$ & Human Capital & 0.529 & 0.085 & 6.246 & $* * *$ & par 5 & $\mathrm{~S}$ \\
\hline
\end{tabular}

$\mathrm{S}=$ significant, NS $=$ Not Significant

The model resulted in the first time which did not require any modification indices analysis. 


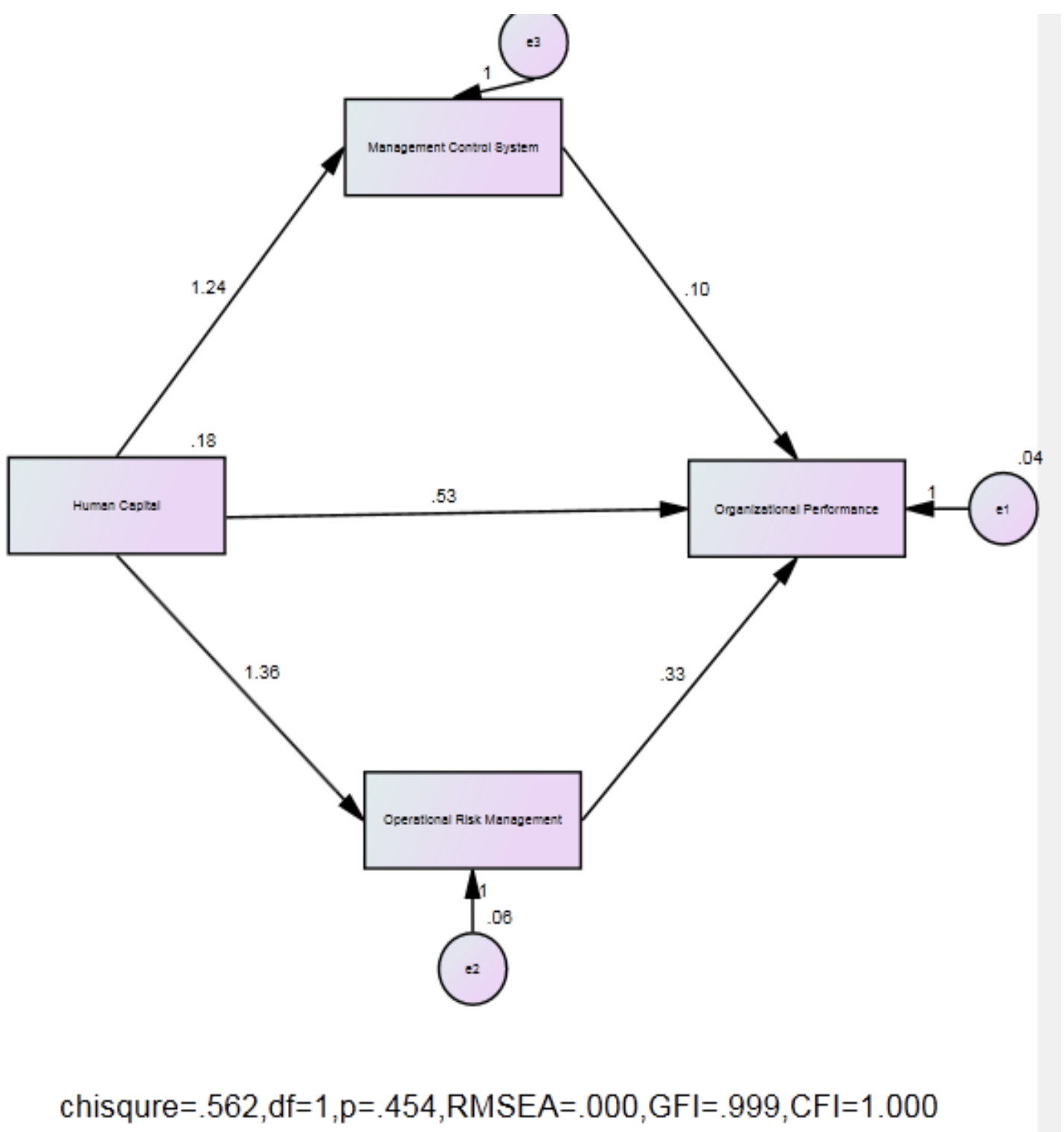

Figure 2. Fit Model for Human Capital impact on Organizational Performance as mediated by management control system and Operational Risk Management.

Table 1

Good Fit Results for Management Control System and Operational Risk Management as Mediators

\begin{tabular}{lcl}
\hline Fit Measure & Results & Verbal Interpretation \\
\hline Chi-square & 0.562 & Good Fit \\
p-value & 0.454 & Good Fit \\
RMSEA & 0.000 & Good Fit \\
CFI & 0.999 & Good Fit \\
GFI & 1 & Good Fit \\
\hline
\end{tabular}

\section{Discussion and Conclusion}

The study have revealed that the null hypothesis which states that management control system and operational risk management do not mediate the relationship between human capital and organizational performance is rejected. The implication of these results is that, whereas human capital can directly predict organizational performance, a further boost to this prediction is obtain on organizational performance when management control system and operational risk management is introduced in to the equation. Their individual effect has been found to be significant.

In support of the mediating effect of operational risk management and management control system on 
organizational performance, Fechete and Nedelcu (2014) study in Rommania within manufacturing industry confirms the influence of operational risk management and management control system on human capital and organizational performance. Again, Oehman, Obechowski, Kenley and Ben-Daya (2014) research also concluded that risk management practices indirectly makes decision making results positively when an organization has high human capital and as a result will lead to high organizational performance. Channa, Abbasi and Maheshwari (2015) also admitted in a comparative study between conventional banks and Islamic banks the effect operational risk and management control when considering human resource and firm's performance. The study makes the recommendation that the intervention role of management control system and operational risk management has shown to impact positively on organizational performance and human capital. Therefore, the implementation of management control system and operational risk management must be paramount to the achievement of organizational performance from the viewpoint of chartered accountants in Ghana.

\section{References}

Arjaliès, D.; Mundy, J. (2013). The use of management control systems to manage CSR strategy: A levers of control perspective. Management. Accounting. Research, 24, 284-300. DOI: 10.1016/j.mar.2013.06.003.

Bamahros, H. M., \& Bhasin, M. L. (2016). Audit Committee Characteristics and Unexpected Accruals: An Empirical Study of Malaysia. Wulfenia, 23, 181-199.

Baron, R. M., \& Kenny, D. A. (1986). The moderator-mediator variable distinction in social psychological research: Conceptual, strategic and statistical considerations. Journal of Personality and Social Psychology, $51,1173-1182$.

Barth, J. R., Caprio, G., \& Levine, R. (2008). Bank regulations are changing: for better or worse? Comparative Economic Studies, 50(4), 537-563.

Channar, Z. A., Abbasi, P. \& Maheshwari, M. B. (2015). Risk management: a tool for enhancing organizational performance (A Comparative Study between Conventional and Islamic Banks). Pakistan Business Review, $1-20$.

COSO, (2004). Enterprise Risk Management- Integrated Framework. Retrieved form: https://www.coso.org/Documents/COSO-ERM-Executive-Summary.pdf

Etu-Menson, F. (2011). Operational Risk Management in the Banking Industry of Ghana.

Fechete, F. \& Nedelcu, A. (2014). Risk assessment affecting organization performance. Advance in Economics, law and Political Science, 190-195.

Felizardo, A., Felix, E.G.S. \& Thomaz, J.P.C.F (2017). Organizational Performance Measurement and Evaluation Systems in SMES: The Case of the Transforming Industry in Portugal. CEFAGE Working Paper. Retrieved from: www.cefage.uevora.pt/pt/content/download/6689/80903/version/1/.../2017 05.pdf.

Fraser, J.; Simkins, B. \& Narvaez, K. (2014). Implementing Enterprise Risk Management: Case Studies and Best Practices. John Wiley \& Sons: Hoboken, NJ, USA.

George, D., \& Mallery, P. (2003). SPSS for Windows step by step: A simple guide and reference. 11.0 update (4th ed.). Boston: Allyn \& Bacon.

Gygi, C. \& Williams, B. (2012). Six sigma for dummies. $2^{\text {nd }}$ Edition, Hoboken: John Wiley \& Sons, Inc.

Hauge, A. L., \& Kanden, D. (2017). Organizational Purpose in Management Control Systems. Retrieved from: https://www.snf.no/Admin/Public/DWSDownload.aspx?File...17.pdf.

Junqueira, E., Dutra, E. V., Zanquetto F, H., \& Gonzaga, R. P. (2016). The Effect of strategic choices and management control systems on organizational performance. Review. Contab. Finance, 27(72), 334-348. Http://Dx.Doi.Org/10.1590/1808-057x201601890.

Kloosterman, V. (2014). What are the 5 risk management steps in a sound risk management process? Retrieved from: http://continuingprofessionaldevelopment.org/risk-management-steps-in-risk-management-process/.

Mitra, S.; Karathanasopoulos, A.; Sermpinis, G.; Dunis, C. \& Hood, J. (2015). Operational risk: Emerging markets, sectors and measurement. European Journal for Operational Research. 2015, 24, 122-132.

Mohammed, H. K. \& Knapkova, A. (2016). The impact of total risk management on company's performance. Procedia - Social and Behavioral Sciences 220:271-277. DOI: 10.1016/j.sbspro.2016.05.499.

Mortin, E.M. \& Audebrand, L.K (2014). Organizational performance and meaning of work: correcting for restricted range. Retrieved from: https://www.researchgate.net/publication/228938395_organizational_performance_and_meaning_of_work_ correcting for restricted rang.

Oehmen, J., Olechowski, A., Kenley, C. R., \& Ben-Daya, M. (2014). Analysis of the effect of risk management practices on the performance of new product development programs. Technovation, 34(8), 441-453. DOI: 10.1016/j.technovation.2013.12.005.

Oehmen, J., Olechowski, A., Kenley, C. R., \& Ben-Daya, M. (2014). Analysis of the effect of risk management practices on the performance of new product development programs. Technovation, 34(8), 441-453. DOI: 10.1016/j.technovation.2013.12.005. 
Peprah, W. K. (2019). The Moderating Effect of Gender on the Relationship Between Intellectual Capital and Audit Quality. Advances in Social Sciences Research Journal, 6(9), 105-115.

Peprah, W. K., \& Ganu, J. (2018). The Convergence of Organizational Culture, Structure and Human Capital Performance: A Conceptual Analysis. Archives of Business Research, 6(5), 212-221.

Peprah, W.K. (2018). Auditors' independence risk - The primary contributing factor to the woe in Ghana's financial sector. Retrieved from: https://www.ghanaweb.com/GhanaHomePage/features/Auditorsindependence-risk-The-primary-contributing-factor-to-the-woe-in-Ghana-s-financial-sector-674459.

PMI, 2008. A guide to the project management body of knowledge (PMBOK guide), 4th ed. Project Management Institute, Drexel Hill, PA.

Rajian, D., Kalambay, H., Mossoko, M., Kwete, D., Bulakali, J., Lokonya, J., Porignon, D., \& Schmets, G. (2014). Health service planning contributes to policy dialogue around strengthening district health systems: an example from DR Congo 2008-2013. BMC Health Services Research, 14:522, doi.org/10.1186/s12913-014$\underline{0522-4 .}$

Weeserik, B. P., \& Spruit, M. (2018). Improving Operational Risk Management Using Business Performance Management Technologies. Sustainability, 10(640), 1-20, doi:10.3390/su10030640. 